eighteen montbs he had not left his ked at the hospital; the lower portion of his body was as good as dead; he fainted at the least movement, and could only be fed with difficulty by an oesophageal tabe. In what was to all appearances a dying condition, Gargam reached Lourdes, and was carried on a stretcher to the shrine. Many of the spectators publicly protested against his being allowed to remain there, as his death in public, which seemed imminent, would have a bad effect on other invalids. Such was the state of the unfortunate man when, during the blessing of the sick by the Blessed Sacrament, he was instantly cured. Immediately after he was taken to the Medical Office to be examined. "His entrance into the office," says Dr. Boissarie, "was one of the most touching sights we ever beheld. Sixty doctors were present, counting hospital surgeons, professors, foreigners; also many representatives of papers, believers and sceptics." The medical examination made the following day proved that M. Gargam was cured, and that although signs of sores recently healed were visible upon the body, the gangrene of the feet had suddenly disappeared. Strength rapidly returned, and to.day M. Gargam frequently spends hours in helping to carry the sick who come to Lourdes in search of relief from their sufferings and maladies at the shrine where he was made whole.

The cure here briefly set forth, and which ai the time was told in the columns of the Daily Mail by a Jewish eye-witness, may be paralleled by many other similar cases. The publicity, however, of the previous history of the Gargam case, and the fact that the man himself may generally be seen engaged in the work of helping the sick at Lourdes at the present day, makes this a case that can easily be inquired into by anyone who will take the trouble to search into the truth of the facts. Other recorded cases, indeed appear to me to be, if possible, even more extraordinary and incapable of any satisfactory natural explanation. Such would be the instantaneous union of bones which had long been broken, and the ends of which had remained separated by a considerable distance. Science would, I believe, require a considerable period of time to effect the union, even if after a long period it would allow the possibility of bringing the ends together at all. Also, I fancy, most people would allow that no mental suggestion, however powerful, would avail to effect a radical cure of this kind in a fow instants.

In view of the constant progress of scientific knowledge, it is quite possible that it might be necessary to qualify former judgements on cures of this kind. The phrase "as far as we know at present" is always usefully appended to a judgement on these matters. Many things which to our forefathers would have appeared impossible are now shown to have a natural explanation. It is for this reason that the official attitude of the Church towards the miraculous is one of extreme caution, and it is this spirit which prevails at Lourdes. The cures there are certain, and the fullest investigation is welcomed, for to us Catholics, whatever be the explanation of how the cure is effected, the supernatural cause is the spirit of the place and the intercession of the Blessed Mother of God.

\section{FAITH HEALING AND MIRACLES.}

By the Rev. Herbert Thurston, S.J.

"OF the miracles of our Lord," says Sir Clifford Allbutt, in his article entitled "Reflections on Faith Healing," "we shall agree that this is not the place to speak." Sir Clifford's motive in counselling this reticence is no doubt one which all will regard with respect, but it is difficult for an advocate of the reality of modern miracles to treat such phenomena altogether apart from what must be held to be their warrant and their prototype in the New Testament. It has been well said by Sir J. R. Seeley in Ecce Homo :

Miracles play so important a part in Christ's scheme, that any theory which would represent them as due entirely to the imagination of His followers or of a later age destroys the credibility of the documents not partially but wholly, and leaves Christ a personsge as my thical as Hercules. 1

1 Ecce Homo, first edition, p. 43, and see this whole chapter on "Christ's Credentials."
There is no documentary theory of the Gospels which can eliminate the element of miracle from the life of our Lord. No modern critic has professed to discover an Ur.Markus or anything of the sort in which we find a portrait of Christ not yet embellished with signs and wonders. Even Professor Adolf Harnack, whom none can accuse of ultra-conservatism, not long since astonished the agnostic world by announcing his belief that the third Gospel was written by Lake the physician; substantially as we have it now, about the year 80, while it is undis puted that several of St. Paul's epistles with their fally developed belief in the Resurrection are considerably older than this. thIardly seems too much to say that Christianity as a moral system is founded on a belief in Christ's miracles. Yet many even of those who take only a philosophical interest in such discussions will shrink from the further conclusion that the moral reformation which Christianity has introduced and the heroism it has engendered were built upon nothing better than a lie.

Strong, then, as our reluctance may be to admit of any departure from the uniformity of Nature's laws, there are not less motives on the other side to lead the thinker who looks back reverently upon the history of the world, and whose own past mistakes have taught him that overconfidence is one of the greatest enemies of all true know. ledge, to pause before he passes summary judgement upon the character of alleged miracles of healing. Writing for such an audience as are likely to come across this intrasion into the pages of a professional journal of one who is medically speaking a layman, I am hardly disposed to ask for more than delay. I plead for arrest of judgement. I ask that the medical critic should not, after a perusal of Zola's Lourdes on the one hand, or of Huysmans's volume ${ }^{2}$ on the other, believe that he has before him the materials for a final conclusion. The wiser philosopher, I submit, will distrust his power of arriving at a safe decision until he is in full possession of the evidence. One recognizes the immense pressure of work and the vast competition of interests in modern conditions of life; but, if I may say it, with all respect for the many eminent authorities who have written of faith healing in the Journal of June 18th, they do not seem to have acquired their information about Lourdes from the best sources. The work of M. Georges Bertrin, for example, Histoire critique des événements de Lourdes, which provides much the most satisfactory general account, has not, I think, been mentioned by any one. ${ }^{3}$ I might add that the majority of the volumes published about Lourdes, not even excepting those of Dr. Boissarie, the President of the Bureau des Constatations, have been written rather for the edification of Catholics, who already believe, than as a presentment of the case for the scientific and the sceptical. This constitutes a special reason for deprecating a too precipitate judgement. The systematic collection of evidence will, no doubt, be very much aided by the canonical investigations which the bishops have recently been directed to make, but so far the scientific discussion of the facts, hampered as it is by immense difficulties in the matter of certificates, etc., has only been possible in a few of the more striking cures.

I plead, then, that the question of modern miracles be approached in a practical spirit, and I cannot but believe that many members of the medical profession who really retain an open mind must already be profoundly impressed by the element of mystery with which they are so often brought into contact in their observations of disease and its cure. Has any one yet offered a satisfactory explana. tion of the latter-day prevalence of appendicitis? Are the successes of so many unorthodox systems of treatment, often, it would seem, fundamentally at variance with the teachings of authorized medicine-homoeopathy, for example, or hydropathy, and more particularly the latest comer, osteopathy 4 -quite ade. quately accounted for? Is any trustworthy analysis available of the causes which underlie the astonishing

${ }^{2}$ Les foules de Lourdes, a work marked by all the exaggerations of the artistic temperament.

3 The excellent English translation of this work by Mrs. Philip Gibbs unfortunately suffers from the omission of valuable note ontrined in the original.

Fow would credit the developments of osteopathy in America. It appears that to total number of graduates in osteopathic colleges in Was 3,946 . as compar expensive menuals of osteopathic treatment are now published in the country. 
results often attained by so simple a remedy as change of air? When one considers the fashions that have prevailed in drugs, health resorts, dietary, or even clothing, or in methods of treatment like bleeding or massage, all in turn believed in, and justified by irrefutable "facts," one is inclined to wonder-I speak as a layman-whether scientific medicine has not hitherto failed to reach something which is perhaps more fundamental than any of the laws which it has undoubtedly discovered. All, at any rate, will agree that the time has not yet come when the accumulation of data can be neglected, and I venture to urge that the surprising phenomena of such places of pilgrimage as Lourdes have not yet received from the medical profession at large such careful study as they require.

And first, before applying myself directly to the question of " miracles," I would invite the reader's attention for a moment to the phenomena of a quite different kind recorded in a recent volume of the Proceedings of the Society for Psychical Research. ${ }^{5}$ Just a year ago I was present at a meeting of that society in which the report was read of certain séances not long before conducted at Naples with the famous medium, Eusapia Palladino. Probably the report would not have impressed me so much had I not had personal knowledge of the resolutely sceptical attitude towards such manifestations of the reader of the paper, the Hon. Everard Feilding, one of the secretaries of the society. Not many months earlier I had heard him declare in terms of strong conviction that, after years of experience with mediums, he had never failed to come upon fraud, and that the results of his experiments in this matter had so far been entirely negative. Or, to quote the statement printed in the volume of the Pro. ceedings referred to, a statement which must have passed under his own eye :

Whilst preserving an open mind as to the possibility of the existence of some hitherto unascertained force in Nature whereby the manifestations testified to by so many observers of high standing were produced, the discovery of repeated fraud had produced in him (Mr. Feilding) an attitude of complete scepticism as regards the probability of his ever finding any example of the exercise of such a force.

The investigation had been conducted by three gentlemen-Messrs. Baggalay, Carrington, and Feilding-all of them of large experience in dealing with the fraudulent practices of mediums, all of them hitherto entirely sceptical as to the existence of any phenomena incapable of being explained by trickery, and two of the three adepts in legerdemain. ${ }^{6}$ The light during the séances was for the most part sufficiently good to follow any pronounced movement of the medium's head or arms. The most rigorous control of a kind taught by long experience was exercised over the position of Eusapia's hands and feet. The séances were held in Mr. Feilding's own room at the hotel, and the possibility of any intervention of accom. plices or of the aid of any prepared mechanical apparatus was put out of the question. Nevertheless, in spite of these and other precautions all the usual manifestations occurred. Tables were levitated, and stools and curtains moved responsive to the medium's gesture. Spectral hands appeared which touched, clasped, and were distinctly felt on many different occasions by each of the three investigators. Noises and lights of all kinds made themselves perceptible; bells, and other such objects which had been left upon the gueridon behind the curtain, sounded of themselves or floated in the air. Nothing could be more puerile than such displays, and nothing more unconvincing than Eusapia's attribution of these phenomena to the spirit of "John King" who was supposed to enter into her in her state of trance. But still if we are to believe human testimony at all, I ventare to say that the reader who will take the trouble to work through the extra. ordinarily minute and candid report which has been published by the investigators, will find himself compelled against his own will to believe that these things actually occurred. The conclusions ananimously arrived at by the investigators referred to will best be given in their own words :

The question, therefore, seems reduced to a choice between two improbabilities. Either we were constantly. thrown into a

5 Vol. xxiii, 1909

6 Mr. Carrington, who is an American, is the author of a book, The Physical Phenomena of Spiritualism (London: Werner Laurie, 19c8). raudulent med but state of hallucination by means of a mysterious, suggestive influence exercised by Eusapia, for the existence of which, either in her or anybody else, there is otherwise, in our view, no evidence whatever; or, on the other hand, the ordinarily recognized laws of dynamics have to be enlarged by the assumption that there does actually exist some hitherto unascertained force liberated in her presence, and for the existence of which, both in her and certain other persons, the body of evidence is, we think, not inconsiderable.

With great intellectual reluctance, though without much personal doubt as to its justice, we adopt the latter alternative Making, then, a reservation for the possibility of some kind of hallucinatory influence of such a kind as fundamentally to invalidate the trustworthiness of all evidence, and for the existence of which we believe there is neither warrant nor parallel, we believe that we have witnessed in the presence of Earapia Palladino the action of some telekinetic force, the nature and origin of which we cannot attempt to specify through which without the introduction of either accomplices, apparatus, or mere manual dexterity, she is able to produce movements of, and percussive and other sounds in, objects at a distance from her and unconnected with ker in any apparent physical manner, and also to produce matter, or the appearance of matter, without any determinable source of supply. ${ }^{8}$

The report of these representatives of our English society might be received with hesitation, in spite of its most impressively thorough character, were it not well known to all interested in such subjects that many of the most eminent psychologists and men of science upon the Continent have taken part in other séances with the same medium, and have in almost every case been convinced of the genuineness of the phenomena produced. Professor Cesare Lombroso, whose fame as a specialist in criminal anthropology is world-wide, was one of the first (that is, in 1891) to make public profession of his belief in Eusapia. Professor Tamburini, who took part in the same set of experiments, made some qualifications, as also at a later date did Professor Richet; but even they admitted, if I may use Professor Richet's words, that, "absurd and unsatisfactory though they were, it seems to me very difficult to attribute the phenomena produced to deception conscious or unconscious or to a series of deceptions." Monsieur and Madame Curie, the discoverers of radium, took the greatest interest in the experiments with Eusapia, and were very much impressed by her. At the Milan séances a committee consisting largely of professors and physicists, and including such men as Professor Schiaparelli, the director of the Milan Observatory, declared by their official report, in reference more especially to the appearance of a hand:

It is impossible to count the number of times that that hand appeared and was touched by one of us; suffice it to say that doubt was no longer possible; it was, indeed, a living human hand which we saw and touched, while at the same time the bust and arms of the medium remained visible, and her hands were held by those on either side of her. ${ }^{9}$

Of English investigators, Sir Oliver Lodge, Sir William Crookes, Mr. Frederic Myers, and, with some qualifications, Professor Henry Sidgwick and Mrs. Sidgwick, have all declared that there seemed no way of accounting for the phenomena except by supranormal means. No doubt, in certain séances at Cambridge, Eusapia was plainly detected in frandalent practices; but this, while thoroughly well known, and while rendering the watchfulness of those who observe her more minute, has not impaired the conviction of those who have had adequate opportunities of testing all the phenomena that the majority of them are genuine. M. C. Flammarion, the astronomer, in his Forces Naturelles Inconnues, 1907, and Dr. Enrico Morselli, the Professor of Pathology in the University of Genoa, in his two volumes entitled Psicologia e Spiritismo, 1907, have both made Eusapia the centre of all their investigations, and have pronounced unhesitatingly in favour of her possession of some faculty hitherto unknown and unexplained. It is not an exaggeration to say that

The opinion of practically all the scientific men [and they include many of the most eminent names in Europe in the domain of psychology] and others who have given any attention by personal experiment to the subject, is that after making every allowance for such fraud as she may occasionally permit herself to indulge in, Eusapia is nevertheless possessed of faculties of some supranormal kind.10

Eusapir Palladino is not, of course, the only medium with regard to whom similar evidence exists. If con-

7 Normally the only persons present were Eusapia, the three investigators, and a shorthand writer chosen by themselves.

Loc. cit., p. 344 .

9 Proceedings of Soc. for Psych. Research, vol. xxiii, p. 313.
10 Proceedings, loc. cit., p. 317 . 
current human testimony can establish any fact at all, there seems no reasonable ground for refusing to believe that D. D. Home on December 16th, 1868, floated out of one window and in at another, thirty feet above the pavement of a London street. The fact was vouched for in the most formal way by the three witnesses who were in the room-Lord Lindsay, afterwards Earl of Crawford, Lord Adare, afterwards Earl of Dunraven, and Captain Charles Wynne-and it is confirmed by the indirect testimony of a number of different persons, amongst the rest Sir William Crookes, who have declared that on other occasions they had seen Home raised several feet from the ground."1

Now, it will not, I trust, be supposed that I am putting the miracles at Lourdes apon the same plane as the levitations and materializations of Home and Eusapis Palladino, but I feel very strongly that if eminent men of science who own no allegiance to the Catholic Church, or any church, can accept the latter in spite of their ntterly purposeless character, there is no reason why an instan taneous cure-which, after all, is far less of a prodigy than a suspension of the law of gravitation-should be rejected a priori. There are, in fact, two reasons why these spiritualistic marvels seem worth appealing to. In the first place, it must be plain that no Catholic ecclesiastic can have any interest in advertising these mediums or their works. So far as the Church of Rome maintains any official attitude towards such manifestations it would treat these apparitions of hands, jangling of instruments, or movements of tables as attributable only to preternatural agencies which, in default of any assignable explanation or reasonable purpose, must be regarded as diabolic. The gospels attribute material and physical effects to the devil, not only in the temptations of our Lord, but also in the maltreatment of the demoniac and the incident of the Gadarean swine. Moreover, the legendary account of Simon Magus (cf. Acts viii, 5, seq.) which is as old as the time of Justin Martyr (c. 150) describes Simon as working miracles by the power of Satan and as raising himself in the air. In the light of the Gospel teaching, it is curious that the spiritualistic medinms are commonly regarded as being possessed by their "control" 12-Eusapia, for example, when she becomes the vehicle of the communications of "John King," speaks in a gruff male voice.

But, secondly, there are few, if any, of the believers in Eusapia who are not keenly alive to the utterly foolish character of her manifestations and to the suspicious features in her performance due to the comparative darkness, the occasional use of fraud and the passivity enjoined on all present. ${ }^{18}$ It is fair to point out that in the miracles of Lourdes no conditions of this kind prevail. Such limitations as seem to exist-for example, no instance is known of the restoration of an amputated limb-seem also to have been generally respected in the miracles of our Saviour Himself.

Turning now to the phenomena at Lourdes, which have been referred to by so many who took part in the discussion on faith healing, I should have liked, if this paper did not threaten to extend to an extravagant length, to offer some criticism upon the historical sketch which forms a notable part of the article of Sir Henry Morris. Perhaps an opportunity may offer of dealing with the subject more at length elsewhere. Let me, then, only say in passing that Berna dette Soubirous's history, both before and after the apparitions, renders it extremely improbable that she should have been selected as a tool to "enlighten the ignorance of the peasantry" regarding the doctrine of the Immaculate Conception. The whole strange story of the apparitions, beginning and ending, in that remote village, within the space of a few weeks, has been minutely recorded. It certainly does great credit to the astuteness of the clergy if they foresaw that so small a spark should kindle so mighty a blaze. Moreover, contemporary documents show that they were so clever in concealing their purpose, that they were praised by the sub-prefect for their abstention from any display of sympathy. Abundant

\footnotetext{
11 See Mr. Andrew Lang, Cock Lane and Common Sense, or the
Dialectical Bociety's Report. and the Life of Home by his widow. Drouk attributable.

13 all grabbing at hends or flosting objects is strictls prohibited at the séances.
}

extracts from the correspondence between the prefect and his deputies may be read in the early part of the volume of Father L. J. M. Cros, Notre Dame de Lourdes, Paris, Retaux, 1901. To this book I may refer those who care to study the history of the apparitions further.

With regard, however, to the miracles themselves, which began to occur in the year of the apparitions, 1858, and have gone on ever since, it is important to observe how different in many respects is the Catholic point of view from that of the faith healer and especially of the Christian Scientist. By the Catholic such cures are never regarded as the natural and ordinary means appointed for the recovery of health. Miracles are always looked upon as a signal boon to which no one can plead any claim of right. Being thus only the manifestation of God's mercy, it is no subject of surprise that a cure should only be accorded partially. No doubt the Paris professors mentioned by Sir Henry Morris were right in saying in the case of Madame Rouchel that "it would have given the Holy Virgin no more trouble to completely cure the lupus than to fill up the perforations in the cheek and palate"; but Christians believe for all that that God bestows His gifts in accordance with His own wise and secret purposes. It would "give Him no more trouble" if He sent all men into the world endowed with perfect health and clear intelligence, but we know that $\mathrm{He}$ does not do so A miracle being, then, something quite extraordinary, and. never to be claimed of right, a man is bound to take all reasonable precautions and to use the natural means which medical science may put within his reach to preserve his own health and that of those de. pendent on him. Again, a miracle in the Catholic idea is something done for the glory of God, and to confirm the faith of the vacillating. Hence, the careful verification of miraculous cures is a praiseworthy act, and the Church invites the fullest publicity, and willingly invokes the aid of science that it may be clearly understood how far the processes of Nature can go, and what lies beyond their province. This attitude towards the verification of miracles is in marked contrast to that of Christian Science; and from this it follows, as I would submit, that when in the case of the Lourdes miracles the character of instantaneousness is claimed for many of them, this claim is in general a reliable one, bat that, from the lack of the habit of any such inquiry and verification, the similar statements made in connexion with the Zionist healings of Dr. Dowie or those of Christian Science com. monly amount to no more than that the patient at a given moment ceased to feel pain.

But by far the most important of the differences between the miracles of Lourdes and those of Dr. Dowie or Mrs. Eddy is, I would urge, to be sought in the fact that whereas the cures of the latter pair can be shown (as, for example, in the book of Mr. Stephen Paget, The Faith and Worlis of Christian Science) to be limited to functional disorders, the cures at the piscina do include many cases of the instantaneous healing of organic disease. Of course, there are a considerable proportion of hysterical patients who go to Lourdes, and these may or may not benefit by the emotional excitement inevitably generated, at least from time to time, in such an atmosphere. But when we see it stated-as it was by so many of those who wrote in these pages a fow weeks ago-that suggestion alone supplies the explanation of the marvels witnessed in the Pyrenees, I feel confident that the distinguished authorities who so expressed themselves would not have spoken thus if they had had fuller reports before them and had had time to study the question more carefully. Two excellent pablications may be referred to as dealing specially with this subject. The one is a medical study of Dr. Vander Elst of Paris (Contribution apportée à la notion d'hystérie par l'étude de l'hypnose, Paris, Vigot Frères, 1908)." In this, though the subject is only touched indirectly, many references are made to the Lourdes miracles. For example, he says, while admitting the existence of hysterical cases, " but it has not been less easy for us to satisfy ourselves of the existence of cures which have nothing to do with functional troubles, but have put an end to ascertained organic mischief. Among the number are such as could not have taken place without destruction or reconstruction of matter. Whatever interpretation one may put upon them or whatever explanation may be given, there can in 
any case be no question of suggestion." The other work, which may be parchased for a few centimes in the series "Science et Religion," is a little book of a more popular character, but it is written by a medical man, Dr. $H$. Lavrand, Professeur à la Faculté libre de Médecine de Lille, who has given special study to the subject. Its name, La suggestion et lles guérisons de Lourdes (Paris, Bloud, 1907), sufficiently indicates the nature of its contents.

I venture to urge, then, that the cases of miracles men. tioned in the Journal- those, for example, of de Rudder (p. 1470), ${ }^{15}$ or of Mme. Rouchel (p. 1459), and otherswould really prove a great deal more than previous contributors seem inclined to concede, if the evidence were more fairly considered, and if weight were allowed to the cumulative effect of a very large number of such cases. The difficulty always urged against the instantaneousness of the cure is the fact that no medical certifi. cate or testimony is forthcoming immediately before the miracle. But surely there are matters-such, for example, as the existence of a hole in Mm. Rouchel's cheek, the presence of a still running purulent discharge, the fact that de Rudder's foot hung loose, and could be turned right round so that the heel was in front and the toes behind-which any fairly intelligent observer can be trusted to bear witness to.

Still such cases are numerous, and I will venture to recall the details of one of more recent date which appears in Dr. Boissarie's last book, and was previously narrated in The Tablet (April 18th, 1908). The following is Dr. Boissarie's report of the case :

Marie Borel, of Mende, 27 years of age, had when 19 an attack of typhoid fever from which she recovered perfectly. Two years later at 21 she began to suffer from appendicitis and remained subject to recurrences of that disease in spite of medical treatment. At the age of 23 an operation was considered necessary, and the appendix was removed at the Montpellier Hospital. The patient left the hospital twenty-five days later apparently quite cured. In a few months, however, an abscess formed where the incision had cicatrized and soon opened spontaneously. The patient began to suffer from abdominal pains and was obliged to enter the hospital at Mende, where an operation was performed by Dr. Bardol with the object of closing the fistula resulting from the abscess. But in spite of this treatment the fistula persisted. The patient then began to complain of pain in the back, and was placed for some time in Bonet's apparatus to give rest to the spine. When the apparatus was removed, the girl was unable to leave her bed, and for thirty months was confined to it. A few months after the appearance of the first abscess a second formed above it, which opened spontaneously. The patient objected to any surgical interference. Some months later a third abscess showed itself on a level with the iliac crest in the axillary line. The patient was now 25 years old, and had three suppurating fistulae, which soon began to give passage to faecal matter. Two other fistulae appeared subsequently in the lumbar region discharging pus. The vertebral column became more and more ankylosed, and the patient was scarcely able to move in her bed. The three fistulae, which discharged faecal matter, began to intercommunicate. A sixth fistala, also discharging faecal matter, was formed later in the neighbourhood of these three. For five months pre ceding the month of August, 1907, the patient had not had a motion through the anus, all the contents of the intestine escaping through the four fistulae in the iliac region. It was a case of artificial anus with several openings. The wounds had to be dressed twice a day, as a considerable amount of pus escaped from the two posterior fistulae. For thirty months before this date the patient could not empty her bladder without the use of a catheter, and from the beginning of the year 1907 the urine had become purulent. With a stiff vertical year 1907 the urine had become purulent. With a stiff vertical column ankylosed in the lumbar region, with the abdominal wall perforated by four apertures opening into the intestine patient was brought to Lourdes in a condition beyond the aid of surgical skill. Her wounds were dressed twice a day on the 19th and 20th of August, 1907. On the morning of the 21st the dressings were removed, and we are told by the nursing ladies that they contained faecal matter anteriorly and pus posteriorly. She was then carried to the piscina. On the afternoon of the

${ }^{15}$ May I say in passing that a striking example of the inadequate connaissance de cause often shown in medical estimates of alleged mirsculous occurrences is offered in Mr. Butlin's note on the de Rudder case (BRITISH MEDICAL JOURNAI, p.1470)? That Mr. Butlin writes in absolute good faith cannot be for a moment in doubt. But when he states that there is no evidence to show whether the bones united in the first months after the accident, this is certainly not a fact admitted by the other side. Dr. Affenaer attended de Rudder immediately he tut the patient suffered so much pain that the bandage had to be removed. Thereupon, we are told, the doctor found ulceration and a gangrenous wound. "Les fragments osseux, baignant dens le pus, dépouillés de leur périoste, n'avaient subi aucun travail de réparation Malgré des soins assidus pendant de longs mois, le Docteur Affenaer ne put obtenir la consolidation." -Dr. A. Deschamps, Un miracle contemporain-Pierre de Rudder, Paris, Bloud, 1903, p. 6. 2lst the dressings were removed before the patient was immersed. To the great surprise of every one, the lint and cotton were quite dry, there was no trace of faecal matter, and posteriorly only a few small yello wish stains. The same morning she had a motion per anum, which had not occurred for the she had a motion per anum, which had not occurred for the had still to be carried on a stretcher. On the 22nd of August after the immersion she felt better and was able to rise unsupported, which she had not done for thirty months. She could also pase urine without the catheter. She then came to the Bureau des Constatations, where she was examined under the direction of Dr. Desplats, of Lille. The dressings, which had not been changed from the previous day, August 2lst, in the morning, were perfectly dry; the fistulae were closed and healed. The vertebral column conld easily be moved in every direction ; the patient leaned forward, backward, sideways. She showed us the certificate of Dr. Bardol [this, it seems, was only dated "August"] who says that she is suffering from purulent and faecal fistulae of the abdominal wall, connected with chronic inflammation of the caecum and appendix, and also from ankylosis of the vertebral column, in consequence of which she is unable either to rise or walk. The patient has been well
ever since, the bowels and bladder have quite recovered their ever since, the bowels and bladder ha
natural function. The urine is clear.16

From a long account of her own condition given by the patient in answer to questions, we learn that the wounds were terribly offensive even after her arrival in Lourdes. Still, she was seen by quite a number of people, who pitied her deplorable state. Unless we suppose a most extraordinary mania for romancing-unlikely in a girl who was so soon, by her own choice, to enter a convent, and who made such a good impression on all observers-it is impossible to doubt that the wounds still discharged faecal matter on the morning of the day before her cure, and this fact was confirmed by the evidence of the ladies who dressed them. On October 15th, 1907, Dr. Bardol, who had been in charge of the case before Marie Borel went to Lourdes, wrote in the following terms :

Marie Borel was for a long time under my care at the hospital of Mende. She suffered; as you say, from fistulas with faecal discharge in the region of the right iliac fossa as a result of lesions in the caecum and the appendix, for which sbe had undergone a first operation at the Montpellier Hospital under Professor Forgues. Later on I myself made a second incision at the hospital of Mende, but I must frankly confess that my explorations in the iliac fossa did not extend very far, and that my finger was soon arrested by a matted growth of false mem. branes which

Since her pilgrimage to Lourdes, Marie Borel has enjoyed wonderfully good health.

It is indisputable that she was cured at Lourdes contrary to all expectation. My friend, Dr. H., who comes from the Paris hospitals, and is a pupil of Charcot, when consulted by me about the case, abstained from offering any medical interpretation. I can only do as he has done, since I belong to the same school which bows before the evidence of facts even when the explanation of the facts is lacking.

(Signed) Dr. BARDOL.

With regard to the same remarkable care, the most recent evidence I have to produce is from an article which appeared in the Etudes for December 5th, 1909. The writer is Dr. Henri Guinier, "ancien agrégé libre de la Faculté de Montpellier," who describes himself as having been well acquainted with Lourdes for forty years, as he commonly took his holidays in that neighbourhood, bat who goes on to add that he was also "sceptique pendant plus de trente ans par education professionnelle, $\dot{a}$ la manière des médecins trop occupés, indifférents ou blasés, qui se bornent a faire de superficielles lectures de comptes rendus incomplets," etc. After briefly recalling the facts of Marie Borel's six abdominal fistulae, he states that he, with a number of other members of his profession, had had the opportunity of examining Marie Borel on August 22nd, 1907, an hour or two after her cure, and again a year afterwards, when she presented herself at the Bureau des Constatations on August 20th, 1908. With regard to August 22nd, 1907, he says : ${ }^{17}$

We saw six abdominal depressions between two and three centimetres in diameter, irrogular, superficial, already slightly coated (tapisses) with a reddish cicatricial tissue in full process of development, which was perfectly dry, and which occupied the site of the fistulae so recently closed. The 20th of August 1908, a year afterwards, every trace of cicatricial tissue had disappeared; upon the healthy skin of the abdomen, now supple and responsive to the touch, there were six patches of redness which marked the position of the former fistulae, but that was all. The abdomen was otherwise absolutely normal.

16 The Tablet, April 18th, 1908, p. 623.
${ }_{17}$ Etudes, December 5th, 1909, p. 595. 
If suggestion can effect such marvels as these, there is no disease, seemingly, with which it cannot cope. But even then we should be puzzled to explain the cure of children under 3 or 4 years of age, of which cases it would be possible to make a not inconsiderable list. One of the most remarkable of these is the case of the little child Aumaitre, the daughter, not yet 2 years old, of a doctor at Nantes, who was instantaneously cured of clubfont at Lourdes when surgical operations had failed to effect any improvement. An account may be found in an article by M. Mangin in the Annales des Sciences Psychiques for 1907 (pp. 858-859).

Another interesting cure is that of a "maladie de Pott" which has been studied by M. Georges Bertrin in a separate brochure entitled Un miracle d'aujourd'hui (Paris, Lecoffre, 1908); but I prefer to pass over this and one or two others in order to note an English case which was made known in the Journal de la Grotte two days after the faith.healing number of the BrITISH MeDICAL JoURNal appeared, and which has since been published in English Catholic newspapers. For a copy of this state. ment I am indebted to the kindness of Mr. Boothman, the father of the patient, and himself a convert clergyman.

1, the undersigned, Edward Duncan Boothman, M.A.Cantab., formerly rector of Shelton, near Stoke-on-Trent, now residing at Compton Lodge, near Dover, make the following declaration before Drs. Boissarie and Cox, in the Bureau des Constatations at Lourdes:

My son, Joseph Duncan Boothman, aged 16 years, here present, miraculously healed, and desiring to be examined by medical experts, has suffered for ten years past from otorrhoea, involving the almost complete destruction of the drum of the left ear, together with chronic suppuration, with intense pain and absolnte deafness, even by condnctivity with the bones of the head. He has been treated by several specialists in Brussels, Dover, and London.

On May 13th Dr. Lake, a distinguished aural surgeon of 60, Harley Street, London, W., declared that the boy's life was in imminent danger, and gave the following certificate:

“60, Harley Street, Cavendish Square, W. "I have examined Master D. Boothman and find a destruction, almost complete, of the drum of the left ear, with chronic suppuration, and I consider an operation advisable, and ultimately necessary.

"12th May, 1910."

"RICHARD LAKe.

He added, after examination hy speculum, that the inflammation had taken an acute form and might at any moment "flare up " and reach the brain, causing death.

At this date my son displayed the following symptoms: Tenderness of the mastoid, and at the base of the ear; purulent offensive suppuration; contraction of the muscles attached to the mastoid, causing the head to lean on the left shoulder; conthe mastoid, causing the head to lean on the left shoulder; constant acute pain in the ear; loss of sleep ; general emaciation of
the body. The diseased ear was quite insensitive to the vibration of a tuning fork applied to the bones of the head; no sound could be heard by the left ear.

In giving the above certificate, Dr. Lake stated that the operation which he deemed "ultimately necessary" had its uncertainties, and that when successfully achieved the boy would be absolutely deaf for life on the left side.

Mr. Boothman then answered that he wished to take the case to a higher power than that of human seience, and that he was beginning a novena to Our Lady of Lourdes.

Dr. Lake replied that evidently upon surgical questions I saw things from a totally distinct point of view from his own; that he fully respected my religious convictions, but he begged me earnestly to lose no time in putting my views to the test of experience, as the danger to my son's life was becoming test of experience, as the danger to my

daily, if not hourly, more threatening.

The novena, or nine days' prayer, was then duly begun, On Sunday, May 22nd, the feast of the Must Holy Trinity, my son was serving mass in the chapel of the Convent of the Augustinian Ladies at Kearsney Manor, near Dover. At the moment of the Elevation of the Sacred Host my son felt a sharp pain in the left ear, and when mass was over, told me of it. He assured me also that the ear was well, the suppuration ceased, and that he could hear better than he had done for years past.

That this was the case soon becsme evident to us all, and we noted a marked change in the boy's features. His sister Mary, who is 15 years old, when she saw him, declared that at frst she did not recognize him owing to the disappearance of the lines of suffering which she had been so long accustomed to observe.

On Monday, May 23rd, Dr. Howden, of Dover, rang me up on the telephone to tell me that he had received a letter from Dr. Lake, asking why the operation he had advised was delayed, warning him that the slightest delay was highly risky. I was able to answer immediately in the telephone: " $\mathrm{My}$ son is bealed; he hears well, I will bring bim to you to-morrow (May 24th) so that you may examine him." Accordingly, on Dr. Howden examined the boy, and pronounced. hearing by conductivity to be normal, and that he could hear the ticking of a watch at the distance of three inches.

On June 2nd the boy was examined by Dr. Murphy, of Dover, who gave his certiflcate in these terms:

“ 24, Waterloo Crescent, Dover.

" Master Boothman was under my care until the 4th of May last, suffering from chronic otorrhoea, with almost complete destruction of left drum. I have to.day examined him and find the ear dry and free from suppuration and the hearing immensely improved.

"June 2nd, 1910 .

"C. F. MURPHY, F.R.C.S."

As he handed me the certificate, he said : "The case is indeed wonderful, and I congratulate you, but you must understand that a recrudescence is possible." I answered, "Doubtless, but it would be equally possible were the healing the result of human science."

Saturday, June 4th, the boy, with his mother and myself, were able to begin our promised pilgrimage. We reached Lourdes on June 7 th, and to. day, June 8th, we present ourselves in the Bureau des Constatations.
(Bigned)
E. Duncan Boothman, M.A.Cantab.

I am unable properly to appreciate the medical aspects of this case, but the cure has so far persisted, and I give it as the most recent example known to me of those wonders of healing at Lourdes which certainly seem to call for more attention than they have hitherto received.

\section{LONDON WATER.}

Report on Bacteriological and Chemical Examinations.

Tye fourth report of Dr. A. C. Houston, Director of Water Examination, Metropolitan Water Board, on the results of the chemical and bacteriological examination of the London waters for the twelve months ended March 3lst, 1910, which has recently been issued, is a monument of conscientious labour and a record of excellent scientific work. The results are carefully tabulated, and the document is full of interesting details. The greater part of the report is of a technical character, and only a short summary can be given here.

Bacteriological Results.

The results of the bacteriological examination are stated as follows:

Raw Water.-The averages of microbes per cubic centimetre for the twelve months were as follows : Raw Thames water-5,268 per c.cm.; highest 19,794 (December), lowest 913 (May). Raw Lee water-37.071 per c.cm.; highest 166,131 (February), lowest 1,679 (September). Raw New River water $-2,801$ per c.cm.; highest 14,989 (December), lowest 515 (May).

It is pointed out that these results have an important bearing on the abstraction figures. In a gravitation scheme, with a superabundant source of supply and huge storage reservoirs, the amount abstracted for storage parposes should be inversely proportional to the current impurity of the water. In the circumstances pertaining to the London supply this is possible only in a partial sense, but attention is again drawn to the fact that the amount of river water abstracted during the months when the river contains an excessive number of bacteria is so large as to emphasize the desirability of passing it through storage reservoirs antecedent to its filtration.

Filtered Waters (including Kent and Lee Valley Unfil. tered Water).-The following statement indicates that the exclusive (that is to gay, exclusive of eamples containing 100 or more microbes per c.cm.) figures for the filtered waters were small, and the percentage reduction effected by the processes of sabsidence and filtration remarkably good:

\begin{tabular}{lr|r|r|r}
\hline & & Thames. & Lee. & New River. \\
\hline Raw water (microbes per c.cm.)... & 5,268 & 37,071 & 2.801 \\
Filtered water (microbes & per & 14.3 & 21.9 & 10.1 \\
$\begin{array}{l}\text { c.cm) } \\
\text { Percentage reduction }\end{array}$... & $\ldots$ & 99.7 & .999 & 99.6
\end{tabular}

Too much strese, however, Dr. Houston says, must not be laid on percentage reduction of microbes. The worse 